\title{
Influence of Mulch and Ridge-tie on Soil Moisture retention and early growth of maize at Jega, Kebbi State, Nigeria
}

\author{
Sanda, Ahmad Rabo ${ }^{1}$, Ahmed Idris Bedi ${ }^{2}$, Musa Ahmed Augie ${ }^{3}$, Calvin Alvin Gaye ${ }^{4}$
}

\author{
${ }^{1,4}$ Department of Graduate School University of the Philippines Los Banos. 4031 Laguna, The Philippines \\ ${ }^{2,3}$ Department of Soil Science, Kebbi State University of Science and Technology, Aliero, P.M.B 1144, Birnin Kebbi, Kebbi \\ State Nigeria.
}

\begin{abstract}
Water is one of the main requirements for healthy plant growth. Most arid and semi-arid regions, however, suffer from insufficient and unreliable rainfall. The prevailing soils generally cannot absorb the amount of water which rainfalls in such a short time. Based on this and many other factors a study was carried out to determine the influence of mulch and ridge tie on moisture retention and early growth of maize, at the Kebbi State University of Science and Technology Teaching and Research Farm Jega. The results shows that on a short term basis ridge tying had the highest amount of moisture, while on the long terms basis mulch had the highest moisture content and maize plant height is also more observed in the mulched plots as compared to ridge-tie respectively with the value of $45 \mathrm{~cm}-75 \mathrm{~cm}$, and $39 \mathrm{~cm}$ al $54 \mathrm{~cm}$ at 3 al 5 WAP respectively al dry matter yield also give a similar trend.
\end{abstract}

Keywords-Mulch, ridge-tie, Moisture, dry spell, climate, infiltration.

\section{INTRODUCTION}

Water and soil nutrition management form a critical components of Agricultural Production. The line between soil and water conservation (SWC) and rainwater harvesting (RWH) technologies for crop production is very thin. SWC can be described as activities that reduce water losses by runoff and evaporation, while maximizing in-soil moisture storage for crop production, but the same could be said of RWH. The two are differentiated by the fact that under soil and water conservation, rainfall is conserved in-site where it falls, whereas under water harvesting a deliberate effort is made to transfer runoff water from a "catchment" to desired area or storage structure (Critchley and Siegert, 1991). The important thing is that both systems complement each other, and under rain-fed agriculture in dry areas, both are necessary nearly all the time.

In the semi-arid areas tie-ridges are made by modifying normal ridges. The techniques involve digging major ridges that run across the pre dominant slope and then creating sub-ridges (or cross-ties) within the main furrows. The final effect is a series of small micro-basins that store rainwater in-site, enhancing infiltration. Depending on the system, the crop is planted at the side of the main ridge, to be as close as possible to the harvested water while also avoiding water logging in case of prolonged rains.

Tied ridges have been found to be very efficient in storing the rainwater, which also resulted in substantial grain yield increase in some of the major dry land crops such as sorghum, maize, wheat, and mung beans in Ethiopia (Georgis and Takele, 2000). The average grain yield increase (under tied ridges) ranged from 50 to over 100 percent when compared with the traditional practice. This increase, however, will vary according to the soil type, slope, rainfall and the crop grown in the dry land areas.

The objectives of mulch is to conserve soil moisture, reduce runoff flows, evaporative losses and wind erosion, prevent weed growth, enhance soil structure and control soil temperature mulching is practiced by famers in the wetter areas due to the availability of vegetative materials. Depending on availability of residues, mulch densities range between 30-70 percent, based on availability of residues obtained from the previous season's crop (Kibwana, 2000). The importance of mulches in reducing surface runoff, soil erosion and evaporation losses cannot be overstated that in the absence of mulch 40-60 percent of the rainfall that fell was lost to evaporation and that if 40-50 percent of the ground was covered with mulch, surface runoff losses were reduced to almost zero and evaporation losses halved (Liniger 1991). Crop yields were found to double or triple and biomass to feed livestock increased.

Based on all the above stated benefits of ridge tie and mulch, thus study which was conducted at the Teaching and Research Farm of the Kebbi State University of Science and Technology, Jega was aimed at evaluating the influence of Mulch and ridge tie on soil moisture retention and early growth of maize. 


\section{MATERIALS AND METHODS}

The trial was conducted at the Teaching and Research farm Jega, of Kebbi State University of Science and Technology, Jega latitude $12^{0} 11^{\prime} \mathrm{N}$, longitude $4^{0} 16^{\prime} \mathrm{E}$ in the Sudan savannah ecological zone. The climate of the area is characterized with an average rainfall of about $500 \mathrm{~mm}-650 \mathrm{~mm}$ per annun, relative humidity ranges from $15^{\circ}-41 \%$ and $50-65 \%$ during the dry and rainy season respectively; temperature average between $14-30^{\circ} \mathrm{C}$ during the cold dry season and $24-41^{\circ} \mathrm{C}$ during the rainy season, the soil of the area has been characterized as sandy loam.

The field was harrowed and made into $5 \mathrm{~m}$ ridges. The plot size was $5 \mathrm{mx} 4 \mathrm{~m}\left(20 \mathrm{~m}^{2}\right)$. A distance of $1 \mathrm{~m}$ was maintained between plots.

The tied ridges are made by modifying normal ridges; sub-ridges are created within the main harrows (or cross ties). The effect here is series of small micro-basins that store rainwater in-site. Straw mulch is applied to those ridges not to be tie after leaving ten ridges that will serve as a control. Speedy moisture tester (Series 2000) was used in moisture determination during the experimental period. Here moisture measurement is made by mixing a weighed sample of a moist soil with Calcium Carbide in the sealed pressure vessel, as the reagent (Calcium Carbide) react with water in the soil sample an acetylene gas will be produce which in turn increase the pressure within the vessel. As the pressure increase in the vessel is proportional to the amount of moisture in the sample, hence moisture content is then read directly from a calibrated pressure gauge. SAMAZ II an improved maize variety was used during the trial. Data relevant to the soil moisture content was taken two times a day that is morning and evening every day, while germination percentage, number of leaves, plant heights and dry matter yield are then taken from the plant up to the time the trial was terminated.

The trial was laid out in a randomized complete block design (RCBD) with a split plot arrangents and replicated three times.

\section{RESULTS AND DISCUSSION}

\subsection{Soil Moisture content as influence by tie-ridge and Mulch:-}

As shown in Table 1, that tie-ridge as it accumulates more water after rainfall it has the higher moisture content as compared to the mulched and the control plots, but as it gets towards afternoon, the moisture content in tie-ridge plots, tend to be lower than that of mulch plots similar results was also obtained by Li Min et al,. 2008, but significantly higher than that of control plots, this indicate that evaporation from the open plots contributed to the moisture depletion from these plots (tie-ridge and control) whereas in the plots that were mulched as a result of the mulch the rate of evaporation even with the increase in the afternoon so temperature little or no effect was observed on it is moisture content from morning to afternoon when the maximum evaporation is taking place, G, Sime, 2014 also found similar results.

TABLE 1

SOIL MOISTURE CONTENT AS INFLUENCED BY TIE-RIDGE AND MULCH AT UNIVERSITY FARM JEGA (\%)

\begin{tabular}{|c|c|c|c|c|c|c|}
\hline \multicolumn{7}{|c|}{ Morning } \\
\hline Days & Tie-ridge & Control & Mulch & Tie-ridge & Control & Mulch \\
\hline 1 & 19.40 & 17.20 & 20.00 & 19.20 & 17.00 & 19.80 \\
\hline 2 & 18.40 & 16.40 & 19.60 & 18.40 & 16.20 & 19.60 \\
\hline 3 & 20.60 & 18.40 & 23.40 & 20.60 & 17.80 & 23.20 \\
\hline 4 & 19.40 & 16.00 & 23.30 & 18.80 & 15.80 & 21.20 \\
\hline 5 & 18.40 & 14.60 & 20.80 & 18.20 & 13.60 & 19.60 \\
\hline 6 & 20.60 & 19.80 & 22.30 & 20.40 & 19.60 & 22.00 \\
\hline 7 & 21.80 & 19.40 & 20.20 & 21.60 & 19.20 & 20.20 \\
\hline 8 & 19.80 & 17.80 & 19.40 & 18.40 & 17.60 & 19.60 \\
\hline 9 & 20.60 & 19.80 & 20.80 & 20.21 & 19.20 & 20.60 \\
\hline 10 & 20.62 & 11.20 & 20.40 & 19.20 & 18.10 & 19.80 \\
\hline 11 & 19.20 & 15.50 & 20.00 & 17.50 & 15.10 & 18.40 \\
\hline 12 & 21.30 & 14.90 & 20.40 & 19.30 & 12.90 & 19.60 \\
\hline 13 & 22.11 & 18.60 & 20.80 & 20.50 & 18.00 & 20.60 \\
\hline 14 & 19.00 & 16.11 & 19.00 & 18.70 & 14.11 & 19.00 \\
\hline 15 & 18.60 & 15.20 & 19.00 & 18.00 & 14.10 & 18.90 \\
\hline 16 & 22.00 & 18.40 & 20.25 & 20.57 & 17.70 & 20.20 \\
\hline
\end{tabular}




\subsection{Effect of Tie-ridge and Mulch on germination count, plant height al dry matter yield of maize}

Mulched plots as compared to ridge tie and control plots show a higher germination count as shows in Table 2 . At 5 WAP (weeks after planting) the number of seeds that germinate in mulched plots is $60 \%$ higher than that of tie-ridge and control plots with the value of 55 and 54\% respectively, the reason of this trend could be attributed to the fact that mulching help to regulate soil temperature and maintain moisture and hence improves the chances of increase in germination count. Plant height was also higher in the mulched plots as compared to the tie-ridge and control plots at both 3 WAP and 5 WAP (weeks after planting) as show in Table 2. At $3 \& 5 \mathrm{WAP}$, the plant height of maize in mulched plots $45 \mathrm{~cm}$ and $75 \mathrm{~cm}$ respectively are much higher as compared to tie-ridge and control plots with the value of $39 \mathrm{~cm}, 54 \mathrm{~cm}, 12 \mathrm{~cm}$ and $43 \mathrm{~cm}$ respectively Adeoye, 1984 and Ahmed, 2008 where they reported that mulch increase plant height and dry matter yield in maize when process of up to 6 tons/ha are used.

TABLE 2

EFFECT OF THE RIDGE-TIE AND MULCH ON GERMINATION COUNT, PLANT HEIGHT AND DRY MATTER OF MAIZE

\begin{tabular}{|c|c|c|c|c|c|c|c|}
\hline Treatment & \multicolumn{3}{|c|}{ Germination count (\%) } & \multicolumn{2}{c|}{ Plant height (cm) } & \multicolumn{2}{c|}{ Dry matter yield (g) } \\
\hline & 5 DAP & 7 DAP & 9 DAP & 3WAP & 5WAP & 3WAP & 5 WAP \\
\hline Tie-ridges & 55 & 67 & 93 & 39 & 54 & 14.3 & 39.2 \\
\hline Control & 54 & 60 & 86 & 12 & 43 & 12.1 & 30.2 \\
\hline Mulched & 60 & 74 & 96 & 45 & 75 & 22.3 & 62.4 \\
\hline
\end{tabular}

*DAP = Days after Planting

** WAP = Weeks after Planting

Dry matter yield of maize at both $3 \mathrm{WAP}$ and 5WAP as shown in table 1 indicates that accumulation of it (Dry matter) is more in the mulched plots as compared to the tie-ridge and control plots. At the said age that is $3 \& 5$ WAP mulched plots give $22.3 \mathrm{~g}$ and $64.4 \mathrm{~g}$ as against the one recorded in tie-ridge and control plots has the values of $14.3 \mathrm{~g} 35.2 \mathrm{~g}$ and $12.1 \mathrm{~g}$ and $30.2 \mathrm{~g}$ respectively. Higher moistures retention and reduced evaporation in the mulched plots could be attributed to this trend.

\section{CONCLUSION}

Moisture retention as a result of low evaporation losses could be attributed to the reasons why mulched plots proves to be better in both amount of moisture, in the soil, higher germination count, plant height and dry matter accumulation of maize plant at Jega.

\section{REFERENCES}

[1] Adeoye, K.B. 1990. Effect and amount of mulch al thinning of mulch application on maize at Samaru, Northern Nigeria Samaru J. Agric. Res. 7: 57-66

[2] Ahmed Rabo Sanda. 2008. Integrated soil and water management strategies and performance of maize at Danbatta and Jangwano village in Kano at Jigawa State. J. Agric. Res. Policies. 3: 73-75

[3] Critchley, W and K. Siegert. 1991. Water harvesting. FOA Rome

[4] G.Sime, J.B. Aune, Mohammed 2014. Agronomic and economic response of tillage and water conservation management in maize at Central rift valley in Ethiopia. Soil and Tillage Research 148 20-30.

[5] Georgis, K. and A. Takele. (2000), Conservation farming technologies for sustaining crop production in semi-arid areas of Ethiopia In: conservation Tillage for dry land farming technological options and experiences in Eastern and southern Africa, eds E.K. Biamah; J. Rockstoom; G.E. Okwach, RELMA Workshop Report No. 3, 142-147

[6] Kibwana, O.T. 2000. Farmer Innovations and their Innovations in land husbandry in Tanzania In: Farmer innovation in land husbandry eds. M. Haile; A, Waters-Bayer; M. Lemma; M, Hailu; G.B. Anenia; F, Abay; Y, Gebre Michael. . Proceeding Workshop (Feb, 6-11-2000) Mekelle Tigray -Ethiopia 53-58

[7] Liniger, H. 1991. Water conservation for rainfed farming in the Semi-arid foot zone North-West of Mt. Kenya. (Laikipia Highlands), $\mathrm{PhD}$ thesis, Laikipia Mount, Kenya papers D-3.

[8] Li-Min Zhou, Feng-Min Li, Sheng-Li and Yajie Song. 2009. How two ridges and the furrow mulched with plastic film affect soil water, soil temperature and yield of maize on the semiarid Loess Plateau of China. Field Crops Research, 113 41-47. 